Association and it will have a co-ordinating role in bringing together people with a common interest but working in different fields. The Committee consists of Professor C. de B. Webb (Chairman), Mr. J. B. Wright (Hon. Sec.), Professor M. Wilson, Dr. C. R. Saunders, Mr. C. M. C. Ndamse, Mr. R. Derricourt, Mr. P. Bonner. The Committee's contact address is c/o the Department of History, University of Natal, Pietermaritzburg, South Africa.

\title{
CEPSE (formerly CEPSI), Lubumbashi, Zaïre
}

From 4 June 1971, when its statutes were modified, the Centre d'Étude des Problèmes Sociaux Indigènes (CEPSI) has been known as the Centre d'Exécution de Programmes Sociaux et Eiconomiques (CEPSE). Its Journal, formerly Bulletin Trimestriel du Centre des Problemes Sociaux Indigènes, then Problemes Sociaux Congolais, is now known as Problemes Sociaux Zaïrois (since no. 94-5, September-December I971).

\section{(Communicated by Professor Luis Beltrán)}

\section{The Swaziland National Centre}

The Swaziland National Centre was planned after Swaziland became independent in 1968, at the request of H.M. King Sobhuza II, as part of the National Archives and the National Museum. These two last developed separately, however, and plans for the National Centre were combined with the National Parks and Monuments. In I97I the Danish Aid Programme DANIDA obtained the services of Mr. Meyer-Heiselberg, formerly curator of the National Museum of Tanzania, as curator of the National Centre from January 1973. An area in Lobamba near the parliament building has been demarcated as the site of the National Archives and the National Centre; in the meantime a temporary centre is being erected from which the construction of the permanent centre can be supervised. Neighbouring museums have expressed interest in the Centre and a reference library has been started. The money already collected is to be used for the temporary centre and, as soon as the work has started, a new fund-raising campaign will be set in motion. The Centre is particularly concerned with making contacts with museums and similar institutions, with finding ways to finance future growth, and with securing experienced technical assistance from abroad. The address is Swaziland National Centre, P.O. Box 75, Mbabane, Swaziland.

\section{Hans Wolff (1920-1967): Memorial Lecture}

A. H. M. Kirk-Greene, Senior Research Fellow of St. Antony's College, Oxford, delivered the 1973 Memorial Lecture as Fourth Visiting Professor in Honour of Hans Wolff at Indiana University on I I April. The subject was " "Mutumin Kirki": The Concept of the Good Man in Hausa'. Professor Wolff published widely on the languages and language problems of Nigeria; he helped to found and edit the Journal of African Languages and also assisted in the early development of the West African Language Conference, serving for several years as Chairman of the African Linguistics Committee of the African Studies Association (USA).

\section{'Agents of Imperialism: The Men Who Ruled Africa, I880-1960'}

ThIs project, which is to be researched and written by Dr. L. H. Gann and Dr. Peter Duignan with assistance from specialists on each colonial power, is to provide a comparative analysis of modern European imperial rule in sub-Saharan Africa and will consider the impact of European dominance on African societies. It will analyse the major features and social relationships of the colonial period and also the relationships among various social groups in the colonies as well as between various colonial powers and their impact on each 